\title{
Identification of Obstacles and Drivers of Smallholder Rubber Farmers to Become Members of A Processing and Marketing Unit in Indonesia
}

\author{
Mirza Antoni ${ }^{1,2}$, Hiromi Tokuda ${ }^{3}$ \\ ${ }^{1}$ Graduate School of Bioresources, Mie University,1577Kurimamachiya-cho, Tsu City, Mie Prefecture, Japan \\ ${ }^{2}$ Sriwijaya University, Indonesia \\ ${ }^{3}$ Mie University, Japan \\ Correspondence: Mirza Antoni, Graduate School of Bioresources, Mie University,1577Kurimamachiya-cho, Tsu City, \\ Mie Prefecture, Japan.
}

Received: January 7, 2019 Accepted: February 11, 2019 Available online: February 20, 2019

doi:10.11114/aef.v6i2.3938～URL: https://doi.org/10.11114/aef.v6i2.3938

\begin{abstract}
The low quality of Indonesian smallholders' rubber material has encouraged the government to make a policy to establish Processing and Marketing Units (PMUs). However, after 10 years of running the policy, the number of smallholder rubber farmers who are members of a PMU is still very small, even though by becoming a member of a PMU, farmers' income increases as a result of rising prices. There have been no studies of the reasons why smallholders have not joined as members of a PMU. Therefore this study tries to discern these reasons and PMUs' performance. The study population comprised 240 smallholders, half of whom represented PMU members and the other half non-members. These were interviewed to record the smallholders' reasons to join or not join a PMU in South Sumatera Province, the largest rubber production area in Indonesia. Constraints for smallholders to join a PMU include already having a customer middleman, debt with the middleman, and the distance from the farmer's house to the middleman's house. Major supports for smallholders to join a PMU include the rubber material price, easily procured support from the government, and the distance of the farmer's house. PMUs' performance did not significantly affect the participation of farmers in becoming or not becoming members. Even though PMUs' performance was good, the interest of smallholders in becoming PMU members did not increase.
\end{abstract}

Keywords: smallholders, customer, rubber material, middleman, PMU, PMU performance

\section{Introduction}

Indonesia is the second largest producer of natural rubber in the world, but the rubber industry faces the main obstacle that the quality of rubber material produced by farmers is still low. Some causes of the low quality of Indonesian rubber. First, $82 \%$ of rubber material is produced by smallholder, the rest by the government and the private sector, $7 \%$ and $11 \%$, respectively (Directorate General of Plantation, 2017). Second, almost all (99.6\%) rubber material produced by smallholders is in the form of thick slabs; $48 \%$ are soaked in water, $66 \%$ do not use recommended coagulum, cleanliness level is $64 \%$, and 55\% is sales frequency every week (Syafira, Agustina, \& Nancy, 2013). Thick slab is the lowest quality form of rubber material. Especially if the frequency of sales is once a week, the dry rubber content is low, so the selling price will be reduced.

Another reason for the low quality is that many smallholder rubber farmers do not join farmer groups. Those who do not join farmer groups do not receive counselling from the government extension staff, such as technical guidance on cultivation and processing of products. Counselling is only provided to smallholders who are members of farmer groups. Through farmer groups the government also provides assistance with production facilities and subsidies for fertilizer prices.

The non-joining of smallholders to farmer groups, besides causing the low quality of rubber material, also can lower the sales prices for rubber. Smallholders who sell rubber material individually will have a weak bargaining position with the middlemen. Moreover, if smallholders have debt with the middlemen, rubber prices will be repressed by these middlemen and the farmers must sell to them (Hasibuan, Lubus, \&Farida, 2014). Additionally, the rubber market structure at the middleman level is characterized by oligopsony market, with moderate concentration and a monopsony 
market at the crumb rubber level (Antoni \& Iskandar, 2015). This condition causes smallholder rubber farmers to become as price-takers.

In response to the issue of low quality and low prices of rubber materials, the central government issued a policy on the establishment of Processing and Marketing Units (PMUs) for rubber material. This policy is intended to encourage farmers to carry out rubber production in groups to achieve economic scale, with a minimum number of 25 members and a minimum land area of 100 hectares. A PMU is a business unit that operates as a place for organizing rubber farmers' technical guidance, processing, temporary storage, and marketing of rubber material. A PMU is expected to be able to improve the quality and price of rubber material. Quality improvement occurs because at the processing stage, farmers are guided in how to produce good quality rubber material, and increasing prices are due to increased quality and marketing carried out jointly or organized through an auction or partnership system (Alamsyah, Nugraha, Agustina and Vachlepi, 2017).

\section{Problem Statements}

Since the issuance of the PMU policy in 2008, only 388 PMUs have been established, and just less than 5\% of rubber material was supplied through PMUs in 2017. This number was still very small when compared to the potential. Every 100 hectares of rubber smallholders' area can create one PMU. Indonesia had 3.1 million hectares of rubber smallholders area in 2017 (Directorate General of Estate Crops, 2017), which can predict that 31,000 PMUs could be established. In fact, to date, only $1.25 \%$ of potential PMUs have been created. These data show that many smallholders still sell through non-PMU channel, especially within the traditional marketing system. However, many studies have found that income, price, and efficiency of PMU marketing channel were more profitable for smallholders than non-PMU marketing channel (Agustina, Alamsyah, \&Nugraha, 2017; Herdiansyah, Nurmalina, \&Winandi, 2015; Husin, Yulius, Dessy, \& Antoni, 2017; Sujarwo, 2015; Syarifa, Agustina, Alamsyah, \&Nugraha, 2016). Therefore this study aims to provide answers to the following research question: Which factors mainly affect smallholders' choice of a PMU or non-PMU marketing channel ?.

\section{Literature Review}

The marketing system for rubber materials in Indonesia is generally divided into two groups: organized and traditional marketing systems (Nancy, Syarifa, Agustina, Alamsyah, \&Nugraha, 2012). The organized marketing system is characterized by marketing conducted in groups, either in farmers' groups or co-operatives, while the traditional marketing system involves marketing by individuals. Organized marketing systems in rubber farming have been implemented since the 1980's through co-operatives that are integrated with the Smallholders Rubber Development Project (SRDP) (Agustina et al., 2017). However, the scope of this program is too small and only formed several cooperatives. As a result the traditional marketing system still dominates the rubber marketing system and rubber quality is mostly low.

Organized marketing systems have been able to improve the quality of rubber material and farmers share. By the organized marketing, rubber material quality was better than traditional marketing. With the high quality of rubber material produced, the farmers share will also be greater. This is because, by selling rubber material through organized marketing, the crumb rubber factories can provide price incentives for the quality of rubber produced by farmers. If crumb rubber factories buy rubber material from organized marketing, they can get good quality rubber, which does not require extra costs in processing it into crumb rubber (Nancy et al., 2012).

The most fundamental obstacles in strengthening the marketing group is lack of farmers' commitment to keep selling rubber by group, lack of awareness to maintain raw rubber material quality, and lack of transparency between board and members of groups. For this group, it is needed guidance and extension about organized marketing and technical guidance in improving quality of rubber material. The most fundamental supporting factors in strengthening the marketing group is a fair dealing between management board and members of group, as well as the activities that were bonding the members, such as: savings and loans, and supplying inputs or groceries for farmers (Syarifa et al., 2016).

PMU is one of the organized marketing systems. PMU is a business unit formed by two or more rubber farmer groups as a place for organizing farmers' technical guidance, processing, temporary storage and marketing of rubber material (Ministry of Agriculture, Republic of Indonesia, 2008).

The PMU channel was more efficient than the others and generated the lowest marketing margin and the highest margin in farmer's share (Herdiansyah et al., 2015). The enforcement of the Regulation of Agriculture Ministry and the Regulation of Trade Ministry had not been done widely at smallholder level, because middlemen agencies still accepted the low quality raw rubber material produced by farmers. The problems of rubber processing and marketing that caused the low quality of raw rubber material and the low of farmers' income were still found in some rubber production area in South Sumatera Province (Syafira, Agustina \& Nancy, (2013).

There was significantly different of rubber farmers' income between PMU members and non PMU members. The 
farmers' income of PMU members who applied auctions and partnerships was 53\% and 64\% larger than farmers in traditional marketing systems. However, incomes of either new marketing system are not significantly different (Husin et al., 2017). This study was supported by (Agustina et al., 2017) that organized marketing system has changed the quality of raw rubber produced by smallholders and increases the farmers' share as well.

The implementation of PMU had a good impact on the quality of rubber material and farmers share, although there are still challenges to be faced. To support the development of the national natural rubber industry it is necessary to provide assistance to PMU, training and guidance on a regular basis that involves as many members of the group as possible. The importance of implementing the right step formulation for the enforcement of sanctions for violation of the rules and application of clean rubber material must be done (Alamsyah et al., 2017).

Factors that significantly influenced smallholders' choice of marketing channel were: (1) location, (2) information access, (3) profitability aspects, and (4) traders' characteristics. Smallholders tended to choose the more beneficial channel when the distance was further, and when the buying price, the rubber quantity and their education was higher (Sujarwo, 2015).

\section{Data and Research Methodology}

The data were collected in 2017 from four regencies in South Sumatera Province, the largest rubber-producing area in Indonesia. Regencies were selected purposely to represent the rubber marketing system of smallholders, while random sampling was further applied in selecting villages and the farmers. The criteria used in selecting villages were that there must be PMU and non-PMU members, and the PMU should already have an applied auction or partnership marketing system. Furthermore, the regency with the largest and the smallest number of PMUs was most preferred. Banyuasin was the selected regency that has the largest number of PMUs, while OganKomeringIlir and OganIlir regencies represented the smallest number of PMUs; all of them used the same marketing system, namely auction. Another selected regency was MusiRawas, in which most smallholders used the partnership system. Primary data were derived from questionnaires used for directly interviewing 240 rubber smallholders in the selected locations. Some 60 samples of smallholders, consisting of 30 PMU and 30 non-PMU members, were randomly taken from a village selected from the targeted regency. Thus the total sample size for the study was 240 rubber smallholders.

Rubber smallholders' reasons for choosing a particular marketing channel were based on the factors of price, kinship, trust, friends, and customers (Hasibuan, et al., 2014). This factor was measured using semi-open questions to explore another reason besides those factors. Respondents were asked to rank their reasonsaccording to the degree of influence.

A PMU's performance was assessed based on its two functions: providing technical services and group business development in rubber processing and marketing. Providing technical activity services consists of providing knowledge about tapping skills, providing knowledge about the use of equipment, and improving the ability of farmers to implement rubber material marketing processing, according to quality standards used by the PMU. Business development activities consist of cooperation in the provision of coagulant materials, cooperation in the provision of production facilities, facilitation with transportation facilities, and capital provision. The performance indicator was assessed witha scoring method used Likert Scale, assigning scores of 3 (very good), 2 (good), or 1 (not good).

\section{Results and Discussion}

\subsection{Smallholders' Reasons for not Joining PMU}

To identify the reasons that farmers joined or did not join a PMU, they were asked to choose among five answers: price, kinship, trust, friend, and customer (Hasibuan, et al., 2014), or to provide other unspecified open-answer options. The options were ranked from most influential (1) to unaffected (4). Each answer in the first rank was given a score of 4, while the second to fourth ranks were scored as 3,2, and 1. Table 1 discloses smallholders' reasonsfor choosing a PMU marketing system.

Table 1 shows that there were 12 reasons farmers chose a PMU marketing channel. The three biggest reasons that encouraged rubber smallholders to choose a PMU system were high price, easy-to-get government facilities, and home distance from the PMU. The high price of rubber material was chosen by one-third of the PMU members. This means that the established purpose of PMUs - for smallholders to obtain higher prices - has been achieved.

The second biggest reason, easy-to-get government facilities, was also relatively high. The government has a policy to provide support only for smallholders who join farmer groups or other agricultural organizations. Government support can take the form of subsidized fertilizer, agricultural extension, agricultural equipment, and seeds. 
Table 1. Smallholders' reasons for choosing a PMU rubber material marketing channel, by rank

\begin{tabular}{lllllll}
\hline \multirow{2}{*}{ Reasons } & \multicolumn{7}{l}{ Chosen by rank (score) } & & \\
\cline { 2 - 7 } & First & Second & Third & Fourth & Total & $\%$ \\
\hline High price & 200 & 81 & 12 & 2 & 295 & 35 \\
Easy to get government facilities & 20 & 39 & 52 & 6 & 117 & 14 \\
Distance from PMU & 56 & 18 & 14 & 10 & 98 & 12 \\
Group & 40 & 27 & 6 & 3 & 76 & 9 \\
Extension employee & 0 & 21 & 34 & 8 & 63 & 7 \\
Get loan from PMU & 36 & 15 & 6 & 1 & 58 & 7 \\
Relationship of family with PMU staff & 16 & 30 & 8 & 0 & 54 & 6 \\
Price transparency & 32 & 9 & 2 & 1 & 44 & 5 \\
Trust & 4 & 15 & 0 & 6 & 25 & 3 \\
Friends & 4 & 6 & 4 & 0 & 14 & 2 \\
Rubber material processing technique & 4 & 0 & 0 & 0 & 4 & 0 \\
Rubber material quality & 0 & 3 & 0 & 0 & 3 & 0 \\
\hline Source: Aut
\end{tabular}

Source: Author, from farmers survey, 2017.

The third biggest reason was the smallholder's distance to the PMU. Sales through a PMU require additional activity to bring the rubber material to the auction place. Smallholders usually use motorcycles to bring the rubber material to the auction place. The closer the proximity of their house or rubber plantation to the auction place, the more likely those smallholders are interested in becoming PMU members. Other reasons affecting smallholders' choice to use PMU marketing channels were relatively small, on average under 10 percent. Some efforts to encourage more smallholders to join PMUs might include the development of more farmer groups, an increase in the extension contribution, PMUs' establishment of financial institutions that can lend money to members, and PMUs' having more active boards,which would invite their families to join the PMU.

Table 2 shows that rubber prices were the biggest attraction for smallholders to join PMUs. However, PMUs' spread was still relatively slow. Many more smallholders were not PMU members. Therefore it is necessary to see also the dominant reasons that cause smallholders to keep non-PMU marketing channels. Considering the smallholders' side, there were 14 reasons they chose anon-PMU marketing channel, as shown in Table 2.

Table 2. Smallholders' reasonsfor choosing non-PMU rubber material marketing channel, by rank

\begin{tabular}{lllllll}
\hline \multirow{2}{*}{ Reasons } & \multicolumn{2}{l}{ Chosen by rank } & & & \\
\cline { 2 - 6 } & First & Second & Third & Fourth & Total & $\%$ \\
\hline Customers & 112 & 99 & 16 & 5 & 232 & 23 \\
Debt & 96 & 36 & 20 & 2 & 154 & 15 \\
Distance home from traders & 52 & 33 & 22 & 6 & 113 & 11 \\
Rubber material price & 12 & 63 & 22 & 11 & 108 & 11 \\
Family connection & 48 & 15 & 16 & 0 & 79 & 8 \\
Simple system & 56 & 15 & 4 & 0 & 75 & 7 \\
Rubber area status & 48 & 3 & 0 & 2 & 53 & 5 \\
Trust & 0 & 30 & 20 & 1 & 51 & 5 \\
Friends & 8 & 9 & 14 & 12 & 43 & 4 \\
Rubber material processing technique & 8 & 9 & 14 & 2 & 33 & 3 \\
No others traders & 24 & 6 & 0 & 0 & 30 & 3 \\
Honesty in weighing & 12 & 3 & 0 & 0 & 15 & 1 \\
Good services & 0 & 0 & 8 & 3 & 11 & 1 \\
Freedom to sell & 4 & 3 & 4 & 0 & 11 & 1 \\
\hline Source: Aund
\end{tabular}

Source: Author, fromfarmers survey, 2017. 
The Table 2 shows that there were four notable reasons for rubber smallholders to choose non-PMU marketing channel. The biggest reason was due to the customer factor with middlemen. This was followed in importance by the smallholders' debt with middlemen, the distance of the smallholder's house with the middleman's house, and the price of rubber. Other reasons were relatively small as drivers of marketing system choice.

The biggest customer-related reason showed a strong smallholder dependence on middlemen. The middleman is a helper for smallholders if they need immediate money; borrowing from middlemen results in guaranteed future rubber sales, and the debt is then paid at the time of the sale. Smallholders' dependence on middlemen continues as long as farmers cannot repay the debt. In addition, middlemen will become customer traders if they not only lend money to smallholders but also apply to buy rubber material at a reasonable price, when weighing the rubber honestly, do not make excessive weight reduction on rubber containing a lot of water and apply payment methods quickly.

Similarly, the second biggest reason was debt to middlemen. This isactually interconnected with the first reason, in regard to the customer. If the middlemen lend money to smallholders, it is almost certain that the smallholders will sell the rubber to them. Smallholders will return the debt from the sale of rubber, and middlemen directly cut farmers' debts at the time of sale. Therefore, as long as smallholders do not have enough income, the dependence on middlemen is high and difficult to move to other marketing systems like PMUs.

The fact that the distance between farmers' houses and middlemen's houses was the third largest farmer did not choose the PMU marketing system, this was prove that kinship among villagers was very strong in the rubber production centres. Farmers feel bad when selling rubber to another trader if there is a middleman near their house. This is thought to be related to one of the functions of the middleman, who can become ahelper if a farmerneeds urgent money. If the farmer has a financial problem, usually the farmer will ask for help from the middleman if family members are not available.

An interesting reason - the price of rubber sold to middlemen through traditional channels - was the fourth biggest reason for farmers to choose non-PMU membership. This proves that the purchase price of middlemen was still quite attractive to smallholders. Nevertheless, a study by Husin et al. (2017) showed that there were significant differences between the prices for farmers who were PMU members compared to non-PMU members. This means, even though the price of rubber on non-PMU channels is lower, but not too much different. Middlemen generally determine the purchase price of rubber on non-PMU channels, beside getting information from the crumb rubber factory, also referring to the prices at the nearest PMU channel. Middlemen buy rubber on non-PMU channels after knowing the auction winner's price on the PMU channel.

\subsection{PMU Performance}

The assessment of PMUs' performance by PMU members showed generally good results. Technical and business development services wereequally good, as presented in Table 3. The best technical services were found in PMUs in MusiRawas Regency, while poor ones were in OganIlir Regency. Technical services were closely related to the duration of PMUs' existence. The PMU in MusiRawas Regency has been established for eight years, while in Oganllir Regency it was only one year. In MusiRawas Regency the chairman of the PMU became a technical staff person, while in OganIlir Regency there were no members as technical staff. Farmers who were members of the PMU in MusiRawas Regency received training for the use of pieces of equipment, both for production and processing of products and marketing knowledge, while the PMU in OganIlir Regency only runs processing and marketing training activities. The assessment of PMU technical service performance is presented in Appendix 1.

Table 3. PMUs' performance based on its function

\begin{tabular}{ccccccccccc}
\hline \multirow{2}{*}{ Activities } & \multicolumn{2}{c}{ Musi Rawas } & \multicolumn{2}{c}{ Banyuasin } & \multicolumn{2}{c}{ OKI } & \multicolumn{2}{c}{ Ogan Ilir } & \multicolumn{2}{c}{ Average } \\
\cline { 2 - 11 } & Score & Criteria & Score & Criteria & Score & Criteria & Score & Criteria & Score & Criteria \\
\hline Technical service function & 9.57 & Very Good & 6.90 & Good & 7.14 & Good & 5.00 & Not Good & 7.15 & Good \\
Business development & 8.10 & Good & 10.40 & Very Good & 6.83 & Good & 5.63 & Not Good & 7.74 & Good \\
\hline Total & 17.67 & Good & 17.30 & Good & 13.97 & Good & 10.63 & Not Good & 14.89 & Good \\
\hline
\end{tabular}


Source: Author, from farmers survey and used likert scale, 2017.

Provision of knowledge about tapping skill activities of rubber farmers was classified as not good, even though in MusiRawas Regency and OganKomeringIlir Regency it was considered good. Only in these two regencies did farmers receive training on tapping skills and processing equipment. Not all members of the PMU received training, however, but only representatives of farmer groups. This situation caused the PMU members' assessment not to be maximal towards the development of rubber farmers' skill.

PMUs' business development activities were classified as very good in Banyuasin Regency but not good in Oganllir Regency. The best PMU business development activities were in Banyuasin Regency. In Banyuasin, the PMU had carried out collaborative activities in supplying coagulant, providing production facilities, and providing transportation facilities to bring rubber material from the farmer's house or garden to the auction place. Only capital provision facilities were not available. The business development activities of the PMU in OganIlir Regency were classified as not good. In this PMU the only activity carried out was cooperation with the provision of coagulant material. Complete business development activitiesin each research location are presented in Appendix 2.

\section{Conclusion}

The higher price of rubber material in PMUs was the biggest attraction for rubber smallholders to become PMU members. This proves that PMUs can increase rubber prices because of the quality of rubber material and the strong bargaining position of smallholders with middlemen. Rubber quality improvement was due to the application of processing standards at the farm level, such as the use of recommended coagulants, as well as to not drying the rubber material or exposing it to direct sunlight, not soaking itin water, and having no contaminants. The bargaining position increases because sales arecarried out by auction or partnership. With the auction system, the bidder with the highest price will win, whereas with the partnership system smallholders can shorten the marketing chain because they sell directly to crumb rubber factories.

Two other reasons that were quite significant in causing smallholders to choose the PMU marketing channel were the ease in getting assistance from the government and the distance of the smallholders' home tothe auction place. The government does not provide assistance to smallholders individually but to farmers who are members of farmer organizations such as PMUs. The distance of the farmer'shouse to the PMU was the third biggest reason because farmers have to incur additional costs to bring the rubber material to the auction site. The PMU office was used as an auction site. If farmers sell usingtraditional marketing, however, middlemen come to farmers so they do not need to incur additional costs.

The biggest reason smallholders did not become PMU members was that they already had customers (permanent middlemen). This reasoning also relates to the second biggest reason, thatfarmerswerebound indebt tothese middlemen. This middleman was usually also a money lender. If farmers already have debt, it is difficult to sell rubber to other buyers. Debt is paid when farmers sell the rubber. The third biggest reason, the distance betweenfarmers'and middlemen's houses, proved that high kinship exists in the rubber production centres. Farmers feel bad when selling rubber to another trader if there is a middleman near their house.

Other reasons many smallholders did not join PMUs was the performance of the PMU. Some PMUs had not provided very satisfying service for members because specificactivities had not been carried out, especially in the relatively newly established PMUs. This service limitation was due to the lack of guidance carried out by the government.

Appendices

Appendix 1. PMU performance based on technical services function

\begin{tabular}{|c|c|c|c|c|c|c|c|c|c|c|}
\hline \multirow{2}{*}{ Activities } & \multicolumn{2}{|c|}{ Musi Rawas } & \multicolumn{2}{|c|}{ Banyuasin } & \multicolumn{2}{|c|}{ OKI } & \multicolumn{2}{|c|}{ Ogan Ilir } & \multicolumn{2}{|c|}{ Average } \\
\hline & Score & Criteria & Score & Criteria & Score & Criteria & Score & Criteria & Score & Criteria \\
\hline Development of rubber farmers' skills & 2.07 & Good & 1.07 & Not Good & 1.87 & Good & 1.00 & Not Good & 1.50 & Not Good \\
\hline Knowledge of the use of equipment & 2.87 & Very Good & 1.13 & Not Good & 1.87 & Good & 1.00 & Not Good & 1.72 & Good \\
\hline Knowledge of processing and marketing & 2.73 & Very Good & 1.80 & Good & 1.50 & Not Good & 2.00 & Good & 2.01 & Good \\
\hline The quality standard used by PMU & 1.90 & Good & 2.90 & Very Good & 1.90 & Good & 1.00 & Not Good & 1.93 & Good \\
\hline Total & 9.57 & Very Good & 6.90 & Good & 7.14 & Good & 5.00 & Not Good & 7.15 & Good \\
\hline
\end{tabular}

Appendix 2. PMU performance based on business development function

\begin{tabular}{|c|c|c|c|c|c|c|c|c|c|c|}
\hline \multirow{2}{*}{ Activities } & \multicolumn{2}{|c|}{ Musi Rawas } & \multicolumn{2}{|c|}{ Banyuasin } & \multicolumn{2}{|r|}{ OKI } & \multicolumn{2}{|c|}{ Ogan Ilir } & \multicolumn{2}{|c|}{ Average } \\
\hline & Score & Criteria & Score & Criteria & Score & Criteria & Score & Criteria & Score & Criteria \\
\hline Cooperation in supply of coagulant & 2.03 & Good & 3.00 & Very Good & 2.40 & Very Good & 2.00 & Good & 2.36 & Very Good \\
\hline Cooperation in supply of production input & 1.20 & Not Good & 2.97 & Very Good & 2.43 & Very Good & 1.63 & Not Good & 2.06 & Good \\
\hline Facilitate for transportation facilities & 2.07 & Good & 3.00 & Very Good & 1.00 & Not Good & 1.00 & Not Good & 1.77 & Good \\
\hline Capital supply & 2.80 & Very Good & 1.43 & Not Good & 1.00 & Not Good & 1.00 & Not Good & 1.56 & Not Good \\
\hline Total & 8.10 & Good & 10.40 & Very Good & 6.83 & Good & 5.63 & Not Good & 7.74 & Good \\
\hline
\end{tabular}




\section{References}

Agustina, D. W., Alamsyah, A., \& Nugraha, I. S. (2017). The improvement of the quality of raw rubber material and farmers' share through the organized marketing system.(Case study in South Sumatra Province, Indonesia. Proceedings of International Rubber Conference).

Alamsyah, A., Nugraha, I. S., Agustina, D. W., \& Vachlepi, A. (2017). TinjauanPenerapan Unit Pengolahan dan Pemasaran Bokaruntuk Mendukung Gerakan Bokar Bersih di Sumatera Selatan. Warta Perkaretan, 36(2), 159-172. https://doi.org/10.22302/ppk.wp.v36i2.307

Antoni, M., \& Iskandar. (2015). Pola PemasaranBahanOlahKaret Rakyat Pada Daerah ProduksiHargaRendah di Pronvinsi Sumatera Selatan. Prosiding Seminar Nasional Lahan Suboptimal, Palembang 08-09 Oktober 2015.

Directorate General of Estate Crops of Indonesia. (2017). Tree Crop Estate Statistic of Indonesia, 2015-2017, Jakarta.

Hasibuan, U. R., Lubus, A., \& Farida, A. (2014). Faktor-faktor yang mempengaruhi perbandingan harga petani karet menjual kepasar lelang dengan non pasar lelang (toke) di Desa Muhajirin Kecamatan Jambi Luar Kota Kabuaten Muaro Jambi. Jurnal Sosi oEkonomi Bisnis, 17(2), 63-71. https://doi.org/10.22437/jiseb.v17i2.2805

Herdiansyah, R., Nurmalina, R., \& Winandi, R. (2015). Increasing in marketing performance of smallholders natural rubber through supply chain optimization. J. TIDP, 2(3), 151-158.

Husin, L., Yulius, Dessy, A., \& Antoni, M. (2017). Effect of different rubber market system on farmer's income in South Sumatra Province, Indonesia. Russian Journal of Agricultural and Socio-Economic Sciences (RJOAS), 11(71), 257-272. https://doi.org/10.18551/rjoas.2017-11.33

Ministry of Agriculture, Republic of Indonesia. (2008). Peraturan Menteri PertanianNomor 38/2008. Pedoman Pengolahan dan Pemasaran Bahan Olah Karet (Bokar). Jakarta, Indonesia: Ministry of Agriculture, Republic of Indonesia.

Nancy, C., Syarifa, L. F., Agustina, D. S., Alamsyah, A., \& Nugraha, I. S. (2012). Development of Rubber Material Marketing in South Sumatera Province. Estate Crops Agency of South Sumatra and Research Institute Sembawa.

Sujarwo, R. M. (2015). Marketing system of smallholder rubber in the Jambi Province, Indonesia. Master's Thesis. Graduate School, Bogor Agricultural University. Bogor, Indonesia.

Syafira, L. F., Agustina, D. S., \& Nancy, C. (2013). Evaluasi pengolahan dan mutu bahan olah karet rakyat (bokar) di tingkat petani karet di Sumatera Selatan. JurnalPenelitianKaret, 31(2), 139-148. https://doi.org/10.22302/jpk.v31i2.141

Syarifa, L. F., Agustina, D. W., Alamsyah, A., \& Nugraha, I. S. (2016). Potensi dan Kendaladalam Penguatan dan Penumbuhan Kelompok Pemasaran Bahan Olah Karet Terorganisir di Provinsi Sumatera Selatan. Jurnal Penelitian Karet, 34(2), 237-246. https://doi.org/10.22302/jpk.v34i2.228

\section{Copyrights}

Copyright for this article is retained by the author(s), with first publication rights granted to the journal.

This is an open-access article distributed under the terms and conditions of the Creative Commons Attribution license which permits unrestricted use, distribution, and reproduction in any medium, provided the original work is properly cited. 